\title{
Teaching NeuroImages: A child with macrocephaly and psychomotor development delay
}

Hajar Rhouda, MD, Latifa Chat, PhD, and Yamna Kriouile, PhD

Neurology ${ }^{\circledR}$ 2019;92:e2397-e2398. doi:10.1212/WNL.0000000000007506

\section{Correspondence}

Dr. Rhouda

hajar.rhouda@gmail.com

Figure Brain MRI

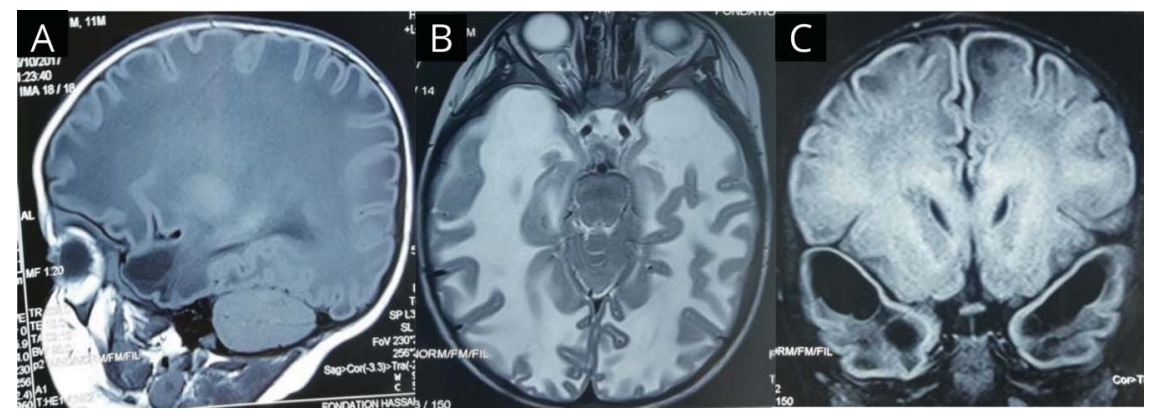

(A) Parasagittal T1-weighted image shows diffuse cerebral white matter hypointensity with temporal subcortical cyst. (B) Axial T2-weighted image shows increased characteristic diffuse supratentorial white matter signal intensity. (C) Coronal fluid-attenuation inverse recovery image shows bilateral symmetrical anterior temporal lobe subcortical cysts.

A 12-month-old boy, born to consanguineous parents, presented with developmental delay and macrocephaly. MRI revealed diffuse cerebral white matter T2 hyperintensity and temporal subcortical cysts (figure), leading to a diagnosis of megalencephalic leukoencephalopathy with subcortical cysts (MLC). Diffuse white matter changes and temporal subcortical cysts are hallmarks of this rare disorder ${ }^{1,2}$; these features, in addition to the lack of basal ganglia involvement, distinguish MLC from other leukodystrophies. ${ }^{1}$ MLC is caused by MLC1 or GLIALCAM mutations leading to a defect of brain ion and water homeostasis. ${ }^{2}$ Clinical features include macrocephaly, mild developmental delay, and easily controlled seizures. ${ }^{1}$

\section{Study funding}

No targeted funding reported.

\section{Disclosure}

The authors report no disclosures relevant to the manuscript. Go to Neurology.org/ $\mathrm{N}$ for full disclosures.

\section{References}

1.- $\quad$ Batla A, Pandey S, Nehru R. Megalencephalic leukoencephalopathy with subcortical cysts: a report of four cases. J Pediatr Neurosci 2011;6:74-77.

2.- Van der Knaap MS, Boor I, Estévez R. Megalencephalic leukoencephalopathy with subcortical cysts: chronic white matter oedema due to a defect in brain ion and water homoeostasis. Lancet Neurol 2012;11:973-985.

\section{MORE ONLINE}

$\rightarrow$ Teaching slides

links.lww.com/WNL/ A884 
Appendix Authors

\begin{tabular}{|c|c|c|c|}
\hline Name & Location & Role & Contribution \\
\hline $\begin{array}{l}\text { Hajar } \\
\text { Rhouda, } \\
\text { MD }\end{array}$ & $\begin{array}{l}\text { Unit of } \\
\text { Neuropaediatrics and } \\
\text { Metabolic Diseases, } \\
\text { Rabat Children's } \\
\text { Hospital; Mohamed V } \\
\text { University, Rabat, } \\
\text { Morocco }\end{array}$ & Author & $\begin{array}{l}\text { Acquisition of data, } \\
\text { drafting of manuscript, } \\
\text { preparation of } \\
\text { publication }\end{array}$ \\
\hline $\begin{array}{l}\text { Latifa } \\
\text { Chat, } \\
\text { PhD }\end{array}$ & $\begin{array}{l}\text { Radiology Department, } \\
\text { Rabat Children's } \\
\text { Hospital; Mohamed V } \\
\text { University, Rabat, } \\
\text { Morocco }\end{array}$ & Author & Interpretation of data \\
\hline $\begin{array}{l}\text { Yamna } \\
\text { Kriouile, } \\
\text { PhD }\end{array}$ & $\begin{array}{l}\text { Unit of } \\
\text { Neuropaediatrics and } \\
\text { Metabolic Diseases, } \\
\text { Rabat Children's } \\
\text { Hospital; Mohamed V } \\
\text { University, Rabat, } \\
\text { Morocco }\end{array}$ & Author & $\begin{array}{l}\text { Acquisition of data, } \\
\text { critical revision }\end{array}$ \\
\hline
\end{tabular}




\section{Neurology}

\section{Teaching NeuroImages: A child with macrocephaly and psychomotor development delay \\ Hajar Rhouda, Latifa Chat and Yamna Kriouile \\ Neurology 2019;92;e2397-e2398 \\ DOI 10.1212/WNL.0000000000007506}

This information is current as of May 13, 2019

\section{Updated Information \& Services}

References

Subspecialty Collections

Permissions \& Licensing

Reprints including high resolution figures, can be found at: http://n.neurology.org/content/92/20/e2397.full

This article cites 2 articles, 0 of which you can access for free at: http://n.neurology.org/content/92/20/e2397.full\#ref-list-1

This article, along with others on similar topics, appears in the following collection(s):

All Pediatric

http://n.neurology.org/cgi/collection/all_pediatric MRI

http://n.neurology.org/cgi/collection/mri

Information about reproducing this article in parts (figures,tables) or in its entirety can be found online at:

http://www.neurology.org/about/about_the_journal\#permissions

Information about ordering reprints can be found online:

http://n.neurology.org/subscribers/advertise

Neurology ${ }^{\circledR}$ is the official journal of the American Academy of Neurology. Published continuously since 1951, it is now a weekly with 48 issues per year. Copyright (O 2019 American Academy of Neurology. All rights reserved. Print ISSN: 0028-3878. Online ISSN: 1526-632X.

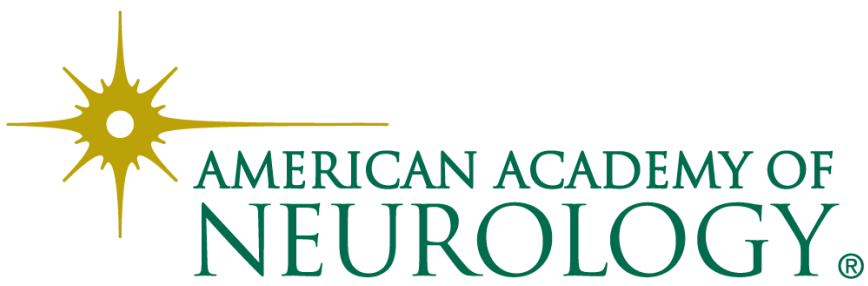

